\title{
Distribution and Extraction of Heavy Metals in Soil and Their Accumulation in Brassica oleracea L. after Long Term Wastewater Irrigation
}

\author{
Faridullah $^{1}$, Farid Ul Haque ${ }^{1}$, Alias Bin Abdullah ${ }^{2}$, Muhammad $\operatorname{Irshad}^{1}$, Arif Alam ${ }^{3} \&$ Akhtar Iqbal $^{1}$ \\ ${ }^{1}$ Department of Environmental Sceinces, COMSATS Institute of Information Technology Abbottabad, Pakistan \\ ${ }^{2}$ Faculty of Arts and Social Sciences, Department of East Asian Studies, University of Malaya, Kuala Lumpur, \\ Malaysia \\ ${ }^{3}$ Department of Development Studies, COMSATS Institute of Information Technology Abbottabad, Pakistan \\ Correspondence: Faridullah, Department of Environmental Sciences, COMSATS Institute of Information \\ Technology Abbottabad, Pakistan. E-mail: faridullah@ciit.net.pk
}

\author{
Received: February 25, 2015 Accepted: April 15, 2015 Online Published: May 15, 2015 \\ doi:10.5539/jas.v7n6p171 URL: http://dx.doi.org/10.5539/jas.v7n6p171
}

\begin{abstract}
Wastewater irrigation has become a common practice especially in third world countries. Over the period of time population growth has resulted in increased domestic and industrial wastes. People produce huge quantities of vegetables and crops yields with wastewater irrigation without knowing its effects on soils, plants and ultimately on consumers. Therefore, a study was carried out to compare accumulation of heavy metals ( $\mathrm{Fe}, \mathrm{Cu}, \mathrm{Pb}, \mathrm{Zn}, \mathrm{and}$ $\mathrm{Cr}$ ) in wastewater irrigated soils with rain fed soils. Water soluble, and total extractable heavy metals were determined. The contents of water soluble, exchangeable and total plant essential elements $(\mathrm{K}, \mathrm{Ca}, \mathrm{and} \mathrm{Mg})$ were also determined. Soil samples from three different layers $(0-30 \mathrm{~cm}, 30-60 \mathrm{~cm}$ and $60-100 \mathrm{~cm}$ depth) were collected from both wastewater irrigated field and rain fed field. Results indicated that water soluble heavy metals varied in soil in order $\mathrm{Fe}>\mathrm{Cr}>\mathrm{Pb}>\mathrm{Zn}>\mathrm{Cu}$ irrespective of the depth and irrigation management. Total heavy metals in all layers of soil were noted as $\mathrm{Cr}>\mathrm{Zn}>\mathrm{Pb}>\mathrm{Cu}>\mathrm{Fe}$ for wastewater irrigated field and $\mathrm{Cr}>$ $\mathrm{Zn}>\mathrm{Pb}>\mathrm{Fe}>\mathrm{Cu}$ for rain-fed field. On the other hand the concentrations of water soluble essential elements varied as $\mathrm{K}>\mathrm{Mg}>\mathrm{Ca}$ for both rain-fed and wastewater irrigated soils. The study clearly indicated that wastewater irrigation caused heavy metal accumulation in both soils and plants. The use of wastewater for agriculture may be economically productive due to abundance of nutrients present in it but have adverse effects on soil, plant and ultimately its consumers. Although heavy metals in plant were found within the standard limits, however, continuation of such practices for a longer period of time may escalate their levels beyond the safe limits.
\end{abstract}

Keywords: heavy metals, wastewater irrigation, cabbage

\section{Introduction}

Wastewater is used for irrigation because of its availability without cost and the scarcity of fresh water. Excessive use of the wastewater for irrigation not only contaminates soil but also the plants (REF). Heavy metals leach down the surface and subsurface soils with repeated applications of wastewater and result in gradual increase in the concentrations of heavy metals in vertical soil column. These heavy metals are taken up by the plants thus posing potential hazard to the human health because of transmission into consumer chain (Burn et al., 2001). The excessive use of heavy metals thus depletes essential nutrients in the body causing several physical and psychological abnormalities. Trace elements requirement is met either through food or water; therefore balanced amount of these metals should essentially be present in food sources. In trace amounts, heavy metals are essentially required for living organisms; however, in higher concentrations they are toxic. The use of wastewater and sewage sludge on agricultural soil has become a common practice in the developing countries, as a result of which these toxic metals can be transferred and concentrated into plant tissues from the soil (Alloway, 1995). At higher concentrations, some metals have strong toxic effects and are regarded as environmental pollutants (Nedelkoska \& Doran, 2000; Chehregani et al., 2005). In soils contaminated with heavy metals, plant growth can be inhibited by metal absorption. However, some plant species are able to accumulate fairly large 
amounts of metals without showing stress, which represents a potential risk for animals and humans (Oliver, 1997).

Potential danger from metal accumulation by plants grown on such soil is becoming an increasing problem throughout the world. This has created a demand for an intensive research effort aimed at predicting the availability of heavy metals in the soil (Nriagu, 1991). Studies have been carried out to analyze heavy metals both in plants and soils. However, distribution of heavy metals in three soil layers of 0-30 cm, 30-60 cm and 60-100 cm depth and their accumulation in cabbage (Brassica oleracea L.) after irrigation with wastewater in Abbottabad, Khyber Pukhtunkhwa province of Pakistan has not been investigated earlier. The objective of the present study was to investigate distribution and extractability of heavy metals in soil irrigated with domestic wastewater of Mirpur village, Abbottabad and its surroundings and hospital wastewater of Ayub Medical Complex, Abottabad and to determine the accumulation of heavy metals in cabbage (Brassica oleracea L.) irrigated with wastewater.

\section{Materials and Methods}

\subsection{Study Area}

General area of study was Abbottabad, Pakistan, urbanizing at a very high population influx rate in recent years. This increase in population posed multifaceted challenges not only for the environment but also for its habitats. The study area was carried out in two adjacent fields, one of which being irrigated by mixture of domestic wastewater of Mirpur and hospital wastewater of Ayub Medical Complex, Abbottabad for cabbage plant (Brassica Oleracea L.). The other adjacent field was rain-fed with the same plants cultivated in it.

\subsection{Soil and Plant Sampling}

Soil sampling was done from 0-30 cm, 30-60 cm and 60-100 cm depths in order to assess the distribution and leaching of heavy metals ( $\mathrm{Fe}, \mathrm{Cu}, \mathrm{Cr}, \mathrm{Pb}$ and $\mathrm{Zn}$ ) in vertical soil column. Plant samples were also collected and lab experiments were performed to find heavy metal accumulation in soils and cabbage plant.

\subsection{Soil Analysis}

Soil samples were air dried, crushed, and sieved $(<0.5 \mathrm{~mm})$ to ensure homogeneity and digested in a mixture of duplicate acids $\left(\mathrm{HNO}_{3}\right.$ and $\left.\mathrm{HClO}_{4}\right)$. Total elements i.e. potassium $(\mathrm{K})$, calcium $(\mathrm{Ca})$ magnesium $(\mathrm{Mg})$, iron $(\mathrm{Fe})$, zinc $(\mathrm{Zn})$, copper $(\mathrm{Cu})$, chromium $(\mathrm{Cr})$, lead $(\mathrm{Pb})$ in the extract of digested soil samples, were determined by atomic absorption spectrophotometer (IBSRAM, 1994). Sample weighing $0.25 \mathrm{~g}$ was digested with $5 \mathrm{~mL}$ concentrated $\mathrm{HClO}_{4}$ by gradual heating over a hot plate for $1 \mathrm{~h}$. After drying $20 \% \mathrm{HNO}_{3}$ was added to the sample and it was heated again for $1 \mathrm{~h}$. The solution was diluted to $50 \mathrm{~mL}$ with deionized water and passed through a $0.22 \mu \mathrm{m}$ filter. Ammonium acetate soluble cations (Ca, $\mathrm{Mg}$ and $\mathrm{K}$ ) were extracted with $1 \mathrm{M} \mathrm{NH}_{4} \mathrm{OAc}$, adjusted to $\mathrm{pH} 7.0$ (Thomas, 1982). The soil samples weighing $3 \mathrm{~g}$ were placed in a $100 \mathrm{~mL}$ centrifuge tube. $25 \mathrm{~mL}$ $\mathrm{NH}_{4} \mathrm{OAc}$ solution was added and was shaken mechanically for $1 \mathrm{~h}$. The supernatant was separated from the soil by centrifugation at $3000 \mathrm{rpm}$ for $10 \mathrm{~min}$. Supernatant is filtered into a $100 \mathrm{~mL}$ volumetric flask. The extract was made up to the volume with deionized water and used for determination of the ammonium acetate soluble cations, $\mathrm{Ca}, \mathrm{Mg}$, and $\mathrm{K}$ and above mentioned heavy metals. The contents were determined using an atomic absorption spectrophotometer.

The above mentioned procedures were used to determine the extracted heavy metals with $1 \mathrm{M} \mathrm{NH}_{4} \mathrm{OAc}$ (Thomas, 1982). Soil texture was determined by the pipette method (Gee \& Bauder, 1986). Soil pH and electrical conductivity (EC) were measured in soil-water $(1: 5 ; \mathrm{w}: \mathrm{v})$ suspensions.

\subsection{Plant Analysis}

Plant tissues were dried in oven on $65{ }^{\circ} \mathrm{C}$ for one hour, crushed, and sieved $(<0.5 \mathrm{~mm})$ to ensure homogeneity and digested in a mixture of duplicate acids $\left(\mathrm{HNO}_{3}\right.$ and $\left.\mathrm{HClO}_{4}\right)$. Total elements i.e. potassium $(\mathrm{K})$, calcium $(\mathrm{Ca})$ magnesium $(\mathrm{Mg})$, iron $(\mathrm{Fe})$, zinc $(\mathrm{Zn})$, copper $(\mathrm{Cu})$, chromium $(\mathrm{Cr})$, lead $(\mathrm{Pb})$ in the extract of digested plant samples, were determined by atomic absorption spectrophotometer (IBSRAM, 1994). Sample weighing $0.25 \mathrm{~g}$ was digested with $5 \mathrm{~mL}$ concentrated $\mathrm{HClO}_{4}$ by gradual heating it over a hot plate for $1 \mathrm{~h}$. After drying $20 \%$ $\mathrm{HNO}_{3}$ was added to the sample and it was heated again for $1 \mathrm{~h}$. The solution was diluted to $50 \mathrm{~mL}$ with deionized water and passed through a $0.22 \mu \mathrm{m}$ filter. The total elemental concentrations of cations and other elements $(\mathrm{K}, \mathrm{Ca}, \mathrm{Mg}$ and above mentioned metals) in plant tissue were determined on an atomic absorption spectrophotometer. Treatments were replicated thrice.

\subsection{Water Analysis}

All the analytical procedures used were the standard methods for water and wastewater analysis (APHA, 2005). 
Wastewater samples were analyzed prior to and after the treatment with used $40 \% \mathrm{H}_{2} \mathrm{O}_{2}$. The BOD was measured by using standard method (APHA, 2005), COD was determined by closed reflux colorimetric method using digester (HACH-LTG 082.99.40001) (APHA, 2005). The wastewater sample, digestion solution and sulphuric acid were digested in vials for two hours at $150{ }^{\circ} \mathrm{C}$. After digestion, absorbance was measured at wavelength $605 \mathrm{~nm}$ in a spectrophotometer (LOVIBOND tintometer GMBH, 44287 DORTMUND). The pH meter (HANNA, HI-991003) was used for $\mathrm{pH}$ determination. $\mathrm{H}_{2} \mathrm{O}_{2}$ was measured according to Tetra Pak Technical data manual by using hydrometer and temperature. The $\mathrm{H}_{2} \mathrm{O}_{2}$ value was obtained after connecting temperature and hydrometer reading on third scale of $\mathrm{H}_{2} \mathrm{O}_{2} \mathrm{~W} / \mathrm{W}$

\subsection{Statistical Analysis}

The data collected during the studies were statistically analyzed using the Stat View software (SAS, 1999). A probability level of $\mathrm{P}<0.05$ was considered significant, and means were separated by Fisher's least significant difference (LSD) test.

\section{Results}

\subsection{Behaviour of Different Elements in Soil}

Concentrations of heavy metals in soils and plants in the area of study were found highly dependent on the source of irrigation. The results of the study indicated that water soluble $\mathrm{K}$ in the rain fed field shows an increasing trend with the soil depth $(0-30 \mathrm{~cm}),(30-60 \mathrm{~cm})$ and $(60-100 \mathrm{~cm})$, whereas in the wastewater irrigated field no significant differences were observed in different layers as shown in Figurela. For rain fed field concentration of water soluble $\mathrm{K}$ was minimum $19.97 \mathrm{mg} \mathrm{kg}^{-1}$ in top soil $(0-30 \mathrm{~cm})$ and noted maximum 23.14 $\mathrm{mg} \mathrm{kg}^{-1}$ in sub soil having depth $(60-100 \mathrm{~cm})$. On the other hand concentration of water soluble $\mathrm{K}$ in the wastewater irrigated field was greater in top soil $28.10 \mathrm{mg} \mathrm{kg}^{-1}$ and lesser was investigated $\left(27.12 \mathrm{mg} \mathrm{kg}^{-1}\right)$ in $60-100 \mathrm{~cm}$ depth. Concentration of extractable $\mathrm{K}$ in wastewater irrigated field was $(0-30 \mathrm{~cm})>(30-60 \mathrm{~cm})>$ $(60-100 \mathrm{~cm})$ (Figure 1b). There is no significant difference between different layers for total $\mathrm{K}$ in rain-fed field as shown in Figure 1c. Total concentration of $\mathrm{K}$ in wastewater irrigated field varied for different layers in order of $(60-100 \mathrm{~cm})>(30-60 \mathrm{~cm})>(0-30 \mathrm{~cm})$. Generally the concentration of water soluble Ca was found higher in the wastewater irrigated field as compared to the adjacent rain fed field. No significant differences were observed for the water soluble $\mathrm{Ca}$ in the three layers of wastewater irrigated field whereas for the rain-fed field maximum water soluble $\mathrm{Ca}$ was noted from $30-60 \mathrm{~cm}$ depth as shown in the Figure 1d. Amount of extractable $\mathrm{Ca}$ was noted almost same in all soil columns in waste water irrigated field (Figure 1e). While comparing the total $\mathrm{Ca}$ in wastewater irrigated field and rain fed field, it was found that total $\mathrm{Ca}$ concentration in wastewater irrigated field was almost 1.5 times greater than the rain fed field. Concentration of total $\mathrm{Ca}$ in the rain fed field varied in different soil columns as $30-60 \mathrm{~cm}>0-30 \mathrm{~cm}>60-100 \mathrm{~cm}$ as shown in the Figure 1f. Concentration of $\mathrm{Mg}$ in all layers of the soils was noted almost same with no significant differences for both types of fields Figure 2a. However, the concentration of water soluble $\mathrm{Mg}$ was slightly lesser $\left(175.40 \mathrm{mg} \mathrm{kg}^{-1}\right)$ in the top soil as compared to the subsoil layers Figure 2a. Extractable Mg varied in the order 60-100 cm $>30-60 \mathrm{~cm}>0-30 \mathrm{~cm}$ in the rain fed field. Contents of total $\mathrm{Mg}$ in rain fed soil are greater as compared with the waste water irrigated soil. Regardless of irrigation source maximum concentration of extractable $\mathrm{Mg}$ was obtained from topsoil (0-30 $\mathrm{cm})$ with $412.83 \mathrm{mg} \mathrm{kg}^{-1}$ and minimum was achieved from the bottom layer $(30-60 \mathrm{~cm})$ with $405.62 \mathrm{mg} \mathrm{kg}^{-1}$ (Figure 2b).
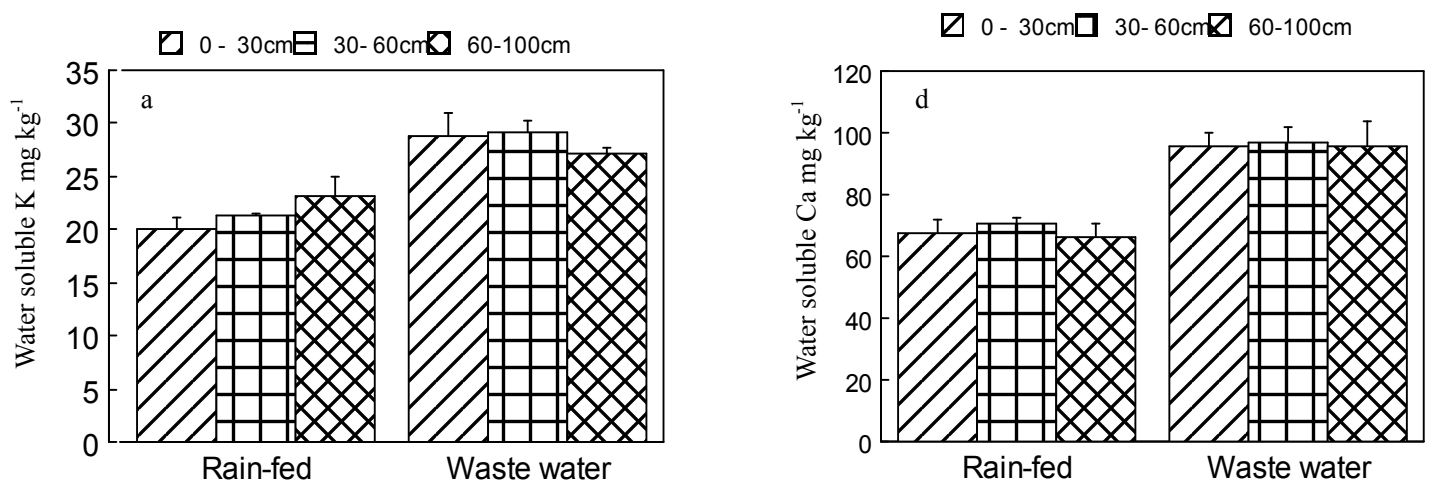

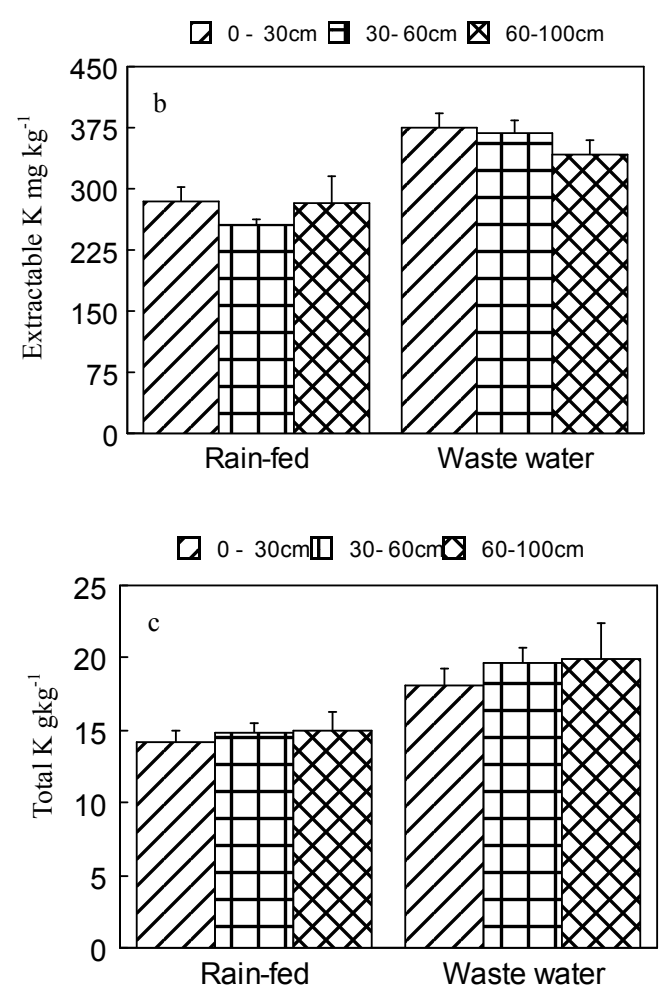
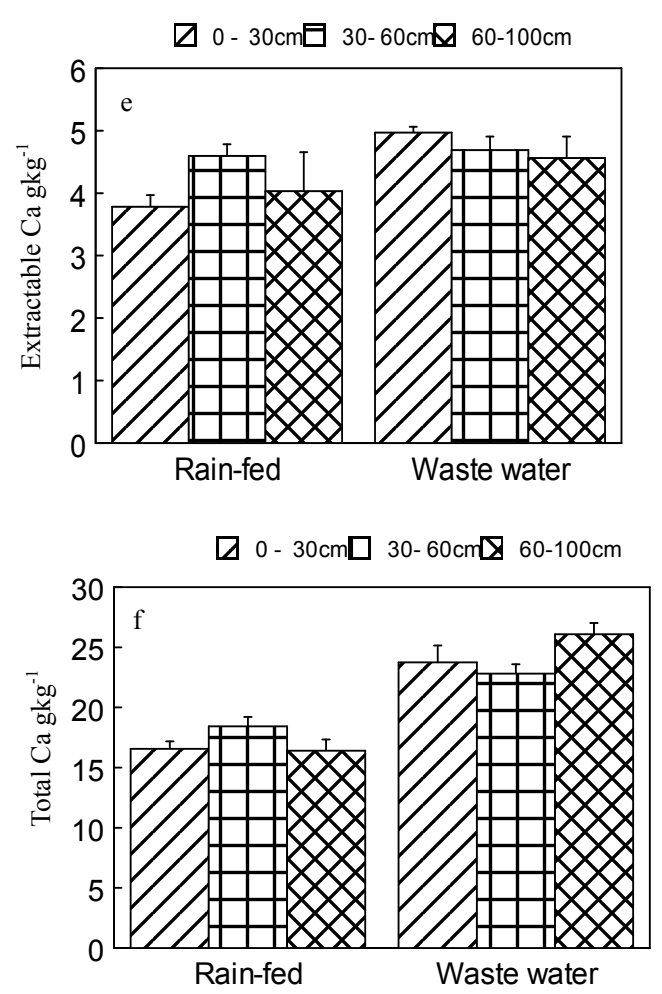

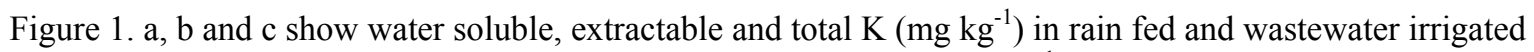
field. While $\mathrm{d}$, e and $\mathrm{f}$ show water soluble, extractable and total $\mathrm{Ca}\left(\mathrm{mg} \mathrm{kg}^{-1}\right)$ in different soil layers in rain fed and wastewater irrigated field
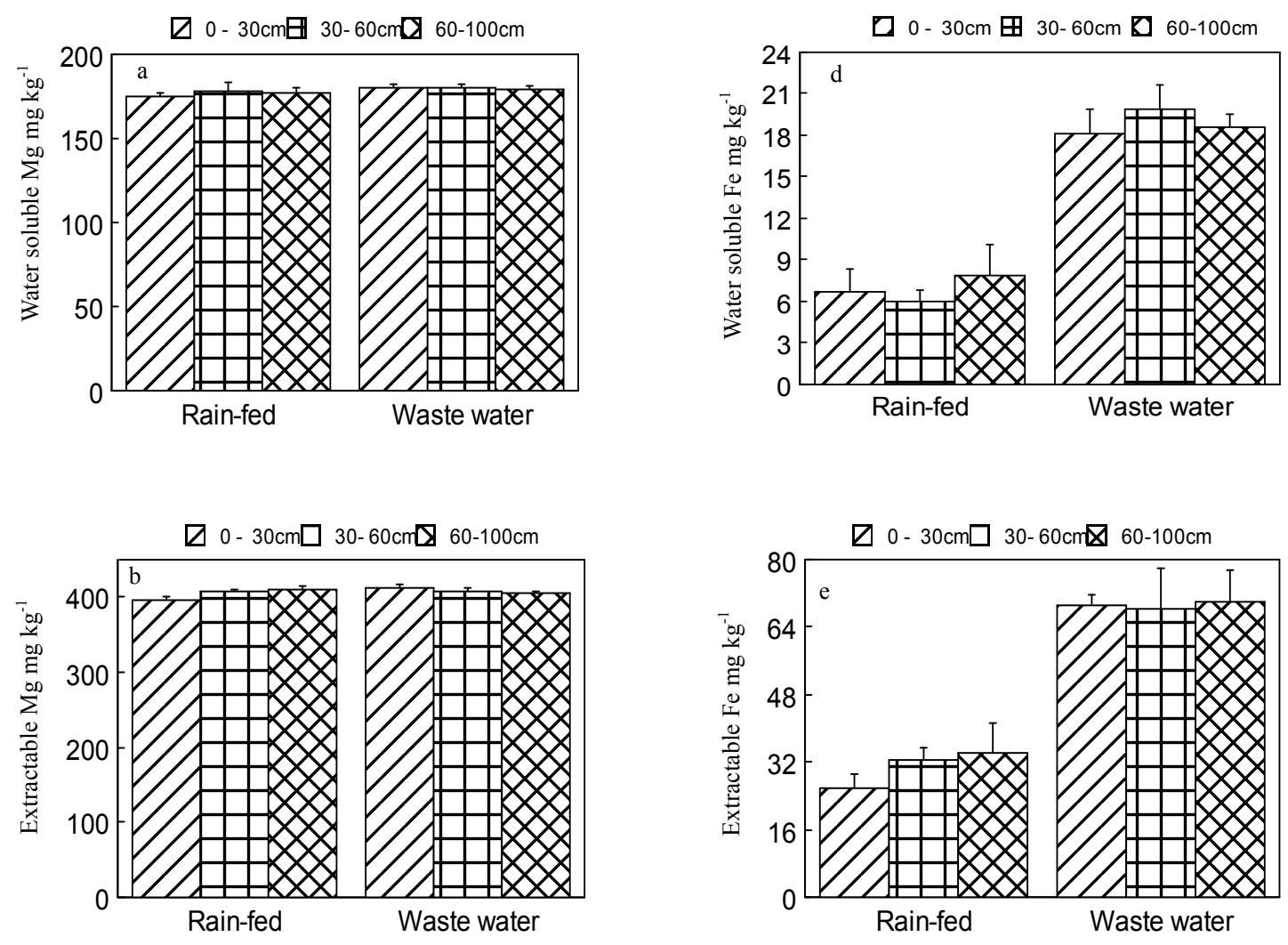

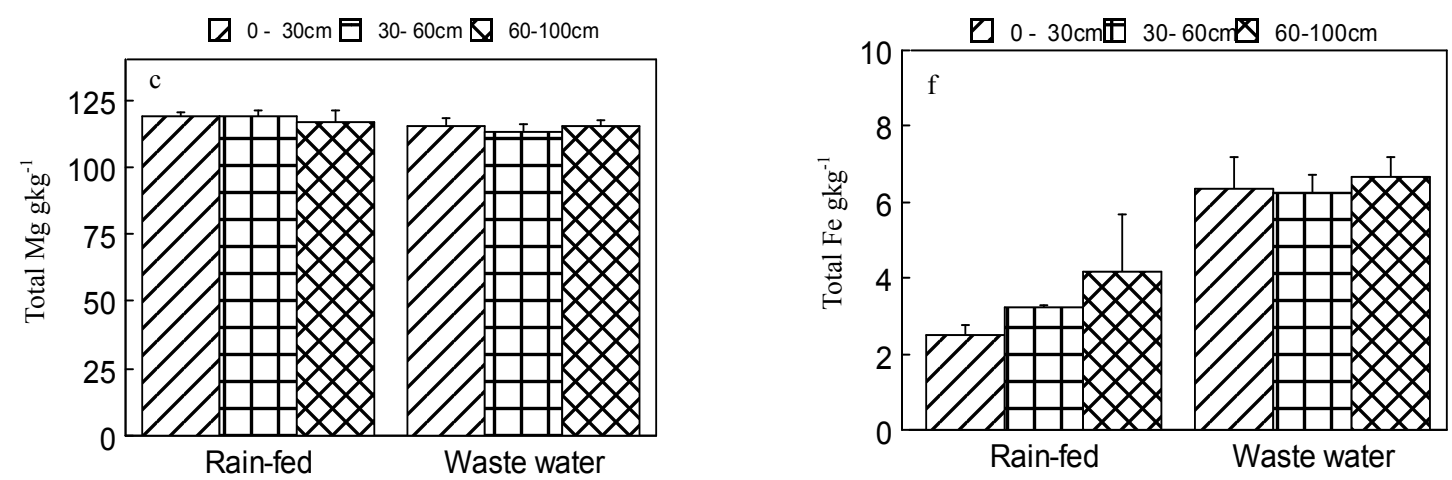

Figure 2. $\mathrm{a}, \mathrm{b}$ and $\mathrm{c}$ show water soluble, extractable and total $\mathrm{Mg}\left(\mathrm{mg} \mathrm{kg}^{-1}\right)$ in rain fed and wastewater irrigated field. While $\mathrm{d}$, e and $\mathrm{f}$ show water soluble, extractable and total $\mathrm{Fe}\left(\mathrm{mg} \mathrm{kg}^{-1}\right)$ in different soil layers in rain fed and wastewater irrigated field

In wastewater irrigated field water soluble Fe varied in order of $30-60 \mathrm{~cm}>60-100 \mathrm{~cm}>0-30 \mathrm{~cm}$ whereas in rain fed field the concentration was $60-100 \mathrm{~cm}>0-30 \mathrm{~cm}>30-60 \mathrm{~cm}$ (Figure 2d). Maximum concentration of extractable $\mathrm{Fe}$ in wastewater irrigated field found in the soil depth $60-100 \mathrm{~cm}\left(70.02 \mathrm{mg} \mathrm{kg}^{-1}\right)$ whereas the minimum value of extractable Fe was observed in the subsoil $\left(68.27 \mathrm{mg} \mathrm{kg}^{-1}\right)$ as shown in Figure 2e. In the rain fed field the amount of extractable $\mathrm{Fe}$ was considerably less as compared with the adjacent wastewater irrigated field as shown in Figure 2e. In the wastewater irrigated field the maximum concentration of total Fe was found in the bottom soil layer $\left(6.68 \mathrm{~g} \mathrm{~kg}^{-1}\right)$ and minimum $\left(6.25 \mathrm{~g} \mathrm{~kg}^{-1}\right)$ amount was observed in the subsoil layer with depth 30-60 cm. In the wastewater irrigated field the total Fe varied in order $(30-60 \mathrm{~cm})<(0-30 \mathrm{~cm})<(60-100$ $\mathrm{cm})$ whereas total Fe varied in the rain fed field as $(0-30 \mathrm{~cm})<(30-60 \mathrm{~cm})<(60-100 \mathrm{~cm})$, however, amount of total $\mathrm{Fe}$ in wastewater irrigated field was noted almost same in different depths of soil with non significant variations (Figure 2f).

Figure 3a shows that water soluble $\mathrm{Zn}$ greatly reduced in the rain fed field as compared to the wastewater irrigated field where slightly higher concentration was found in top layer of soil $(0-30 \mathrm{~cm})$ with $0.43 \mathrm{mg} \mathrm{kg}^{-1}$. Amount of water soluble $\mathrm{Zn}$ as observed in the rain fed field varied in order $60-100 \mathrm{~cm}>30-60 \mathrm{~cm}>0-30 \mathrm{~cm}$. Accurate measurements of the total metal contents in polluted soils are required to assess the potential risk of these areas. Higher total $\mathrm{Zn}$ contents were found in the wastewater irrigated field, whereas in the rain fed field the concentration of total $\mathrm{Zn}$ was decreased. In wastewater irrigated field total $\mathrm{Zn}$ concentration was observed higher with maximum amount of total $\mathrm{Zn}\left(79.93 \mathrm{mg} \mathrm{kg}^{-1}\right)$ in topsoil. Minimum amount of total $\mathrm{Zn}(59.83 \mathrm{mg}$ $\left.\mathrm{kg}^{-1}\right)$ was found in the soil layer having depth $30-60 \mathrm{~cm}$. Concentration of total $\mathrm{Zn}$ was observed lesser $(22.3 \mathrm{mg}$ $\mathrm{kg}^{-1}$ ) in rain fed field in top soil layer $0-30 \mathrm{~cm}$ while its maximum value was observed in the bottom soil layer as shown in Figure 3c.
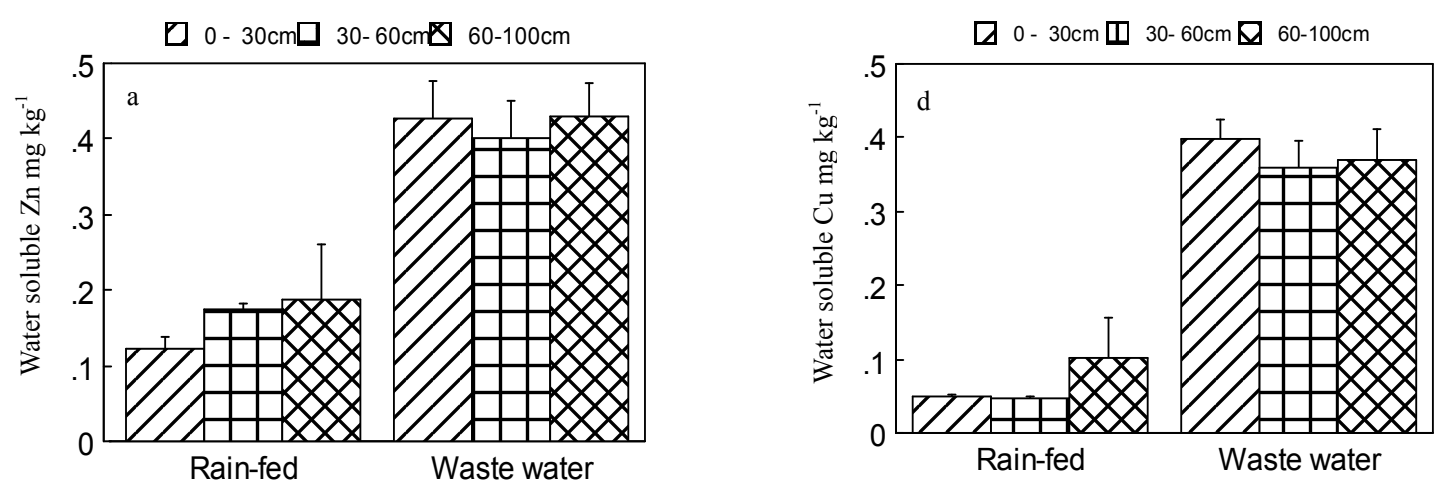

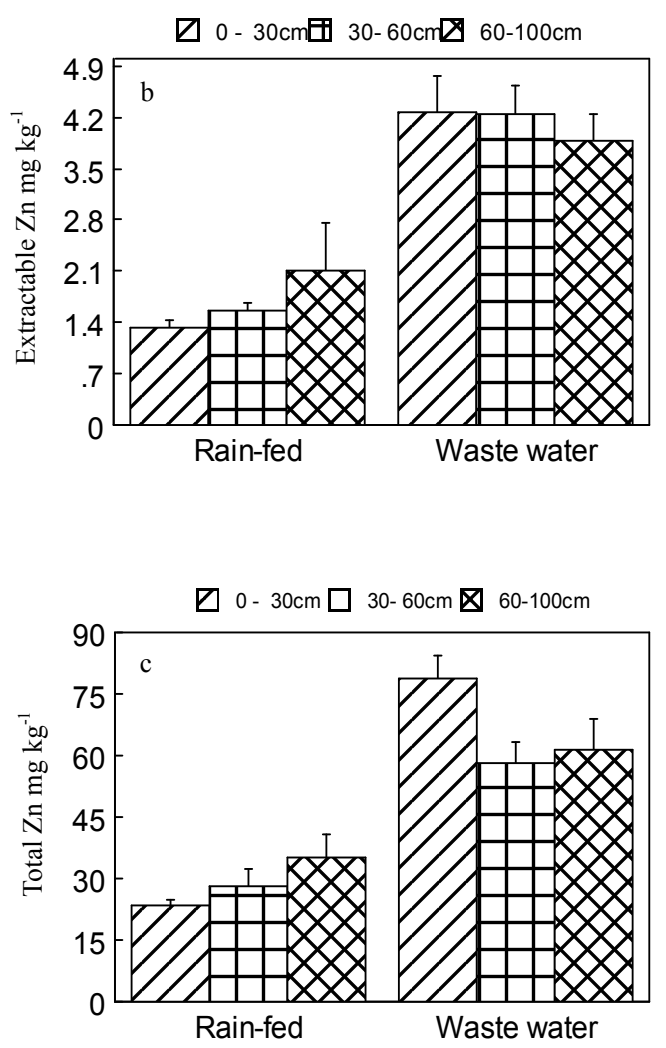
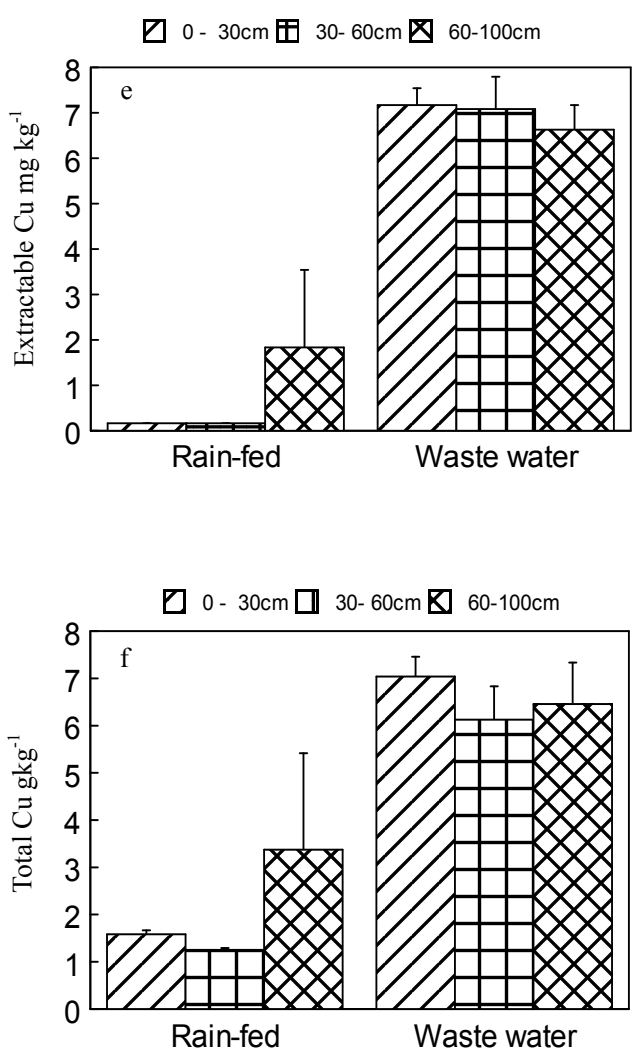

Figure 3. a, b and c show water soluble, extractable and total $\mathrm{Zn}\left(\mathrm{mg} \mathrm{kg}^{-1}\right)$ in rain fed and wastewater irrigated field. While $\mathrm{d}$, e and $\mathrm{f}$ show water soluble, extractable and total $\mathrm{Cu}\left(\mathrm{mg} \mathrm{kg}^{-1}\right)$ in different soil layers in rain fed and wastewater irrigated field

Amount of water soluble $\mathrm{Cu}$ in rain-fed field is negligibly lesser in all soil columns and found more than three times higher in the wastewater irrigated field. Within the soil column in the wastewater irrigated field the concentration of water soluble $\mathrm{Cu}$ was found significantly higher in the top soil $\left(0.39 \mathrm{mg} \mathrm{kg}^{-1}\right)$ and observed minimum $\left(0.35 \mathrm{mg} \mathrm{kg}^{-1}\right)$ in the subsoil layer with depth $30-60 \mathrm{~cm}$ with marginal differences as shown in Figure $3 \mathrm{~d}$. In the rain fed field concentration of water soluble $\mathrm{Cu}$ was noted negligibly small $\left(0.05 \mathrm{mg} \mathrm{kg}^{-1}\right)$ in the top soil and slightly higher $\left(0.10 \mathrm{mg} \mathrm{kg}^{-1}\right)$ as shown by Figure $3 \mathrm{~d}$. The order of extractable $\mathrm{Cu}$ concentration in the wastewater irrigated field was noted as $0-30 \mathrm{~cm}>30-60 \mathrm{~cm}>60-100 \mathrm{~cm}$. The concentration of extractable $\mathrm{Cu}$ in the rain fed field was negligible $\left(0.17 \mathrm{mg} \mathrm{kg}^{-1}\right)$ in the topsoil and subsoil column but its concentration increased in the bottom layer to $\left(1.8 \mathrm{mg} \mathrm{kg}^{-1)}\right.$ as shown in Figure 3e. The amount of total $\mathrm{Cu}$ in the wastewater irrigated field was observed higher and noted relatively lesser in the adjacent rain fed field. Total $\mathrm{Cu}$ contents in the wastewater irrigated field varied in order of $0-30 \mathrm{~cm}>60-100 \mathrm{~cm}>30-60 \mathrm{~cm}$ as shown by Figure $3 \mathrm{f}$.

Although $\mathrm{Cr}$ is required in trace amounts for sugar and lipid metabolism and in larger amounts it can be toxic. Water soluble $\mathrm{Cr}$ contents in the wastewater irrigated field were found significantly higher as compared with the adjacent rain fed field. In wastewater irrigated field the amount of water soluble $\mathrm{Cr}$ in soil layer $60-100 \mathrm{~cm}$ was found increased to $6.17 \mathrm{mg} \mathrm{kg}^{-1}$ and subsoil layer $(30-60 \mathrm{~cm}$ ) water soluble $\mathrm{Cr}$ concentration was decreased to $5.61 \mathrm{mg} \mathrm{kg}^{-1}$ (Figure 4a). In the rain fed field maximum water soluble Cr contents $\left(4.60 \mathrm{mg} \mathrm{kg}^{-1}\right)$ were found in the bottom soil layer $(60-100 \mathrm{~cm})$. Concentration of water soluble $\mathrm{Cr}$ varied in the rain fed field in order of $60-100 \mathrm{~cm}>0-30 \mathrm{~cm}>30-60 \mathrm{~cm}$. The value of extractable $\mathrm{Cr}$ was found almost double in the wastewater field and lower in the rain fed field (Figure $4 \mathrm{~b}$ ). Total $\mathrm{Cr}$ was found increased in the wastewater irrigated field by an appreciable amount as compared to the rain fed field. Maximum total $\mathrm{Cr}\left(128.78 \mathrm{mg} \mathrm{kg}^{-1}\right)$ was found in the subsoil $30-60 \mathrm{~cm}$ while minimum concentration $\left(122.42 \mathrm{mg} \mathrm{kg}^{-1}\right)$ was observed in the top soil column. Total $\mathrm{Cr}$ varied in the rain fed field in the order 60-100 $\mathrm{cm}>30-60 \mathrm{~cm}>0-30 \mathrm{~cm}$ (Figure 4c). 

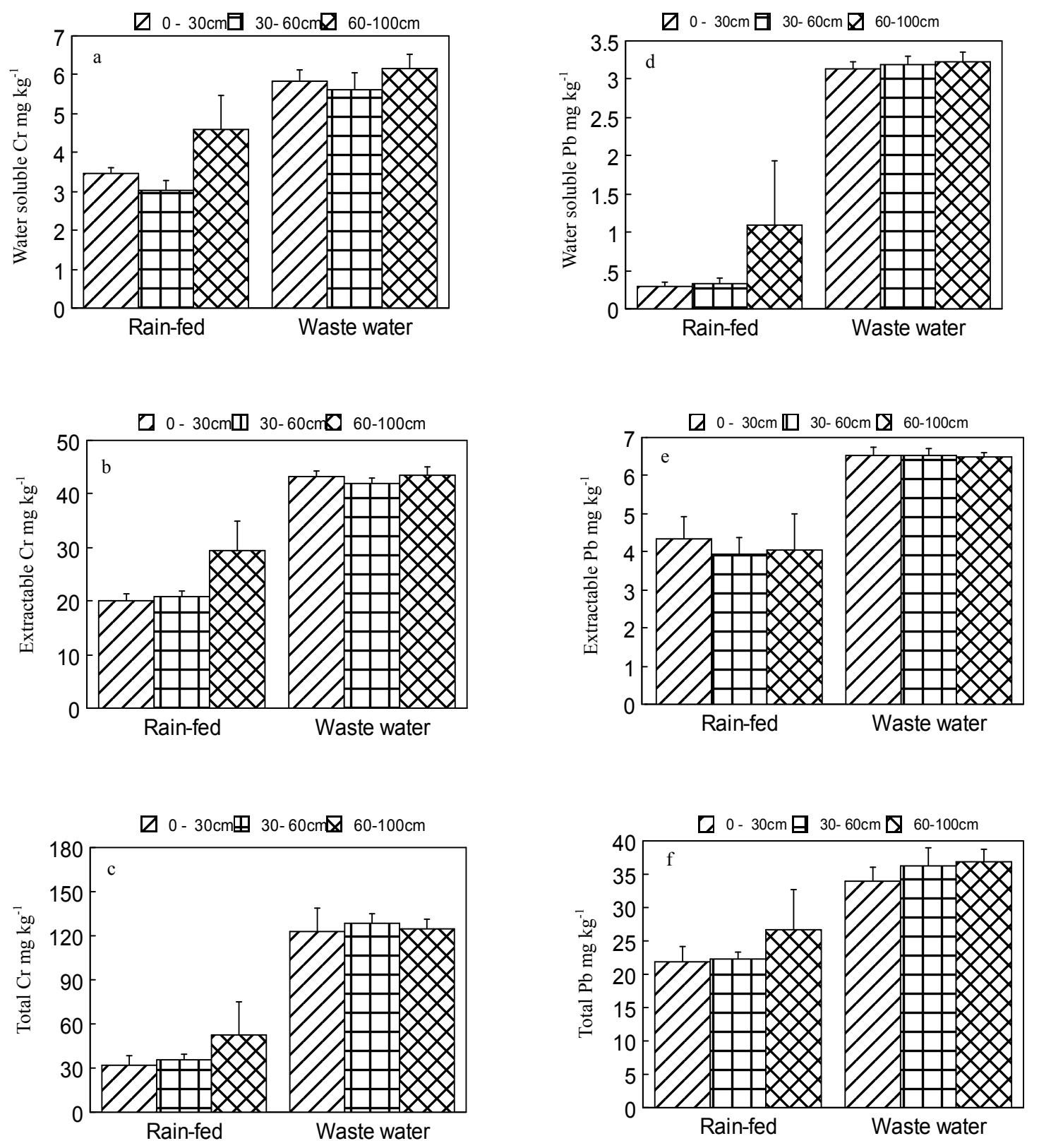

Figure 4. a, b and c show water soluble, extractable and total $\mathrm{Cr}\left(\mathrm{mg} \mathrm{kg}^{-1}\right)$ in rain fed and wastewater irrigated field. While $\mathrm{d}$, e and $\mathrm{f}$ show water soluble, extractable and total $\mathrm{Pb}\left(\mathrm{mg} \mathrm{kg}^{-1}\right)$ in different soil layers in rain fed and wastewater irrigated field

Concentration of water soluble $\mathrm{Pb}$ was observed higher in the wastewater irrigated field as compared to the adjacent rain fed field as shown in Figure 4d. No significant differences in concentration of water soluble $\mathrm{Pb}$ were found in all three layers of wastewater irrigated field, however, significant variations were recorded for water soluble $\mathrm{Pb}$ in the adjacent rain fed soil. The amount of extractable $\mathrm{Pb}$ was observed higher in the wastewater irrigated field. Extractable $\mathrm{Pb}$ varied in the rain fed field in the order 0-30>60-100 cm $>30-60 \mathrm{~cm}$ (Figure 4e). Total $\mathrm{Pb}$ concentration was found higher in the wastewater irrigated field and observed lower in the rain fed field. Maximum amount of total $\mathrm{Pb}\left(36.83 \mathrm{mg} \mathrm{kg}^{-1}\right)$ was noted in the soil column $(60-100 \mathrm{~cm})$ in the wastewater irrigated field as shown in Figure 4f. Total $\mathrm{Pb}$ concentration was minimum the topsoil column (21.93 $\mathrm{mg} \mathrm{kg}{ }^{-1}$ ) of rain fed soil.

\subsection{Behaviour of Different Elements in Plant}

Concentration of $\mathrm{K}$ found higher in the wastewater irrigated cabbage shoots as compared with the adjacent 
rain-fed field as shown in Figure 5a. Plant sampling was done from three random sites Site A, Site B and Site C in each field. Potassium contents were maximum in Site $\mathrm{A}\left(0.57 \mathrm{mg} \mathrm{kg}^{-1}\right)$ and minimum in Site B $\left(0.50 \mathrm{mg} \mathrm{kg}^{-1}\right)$ Figure 5a. Amount of $\mathrm{Ca}$ and $\mathrm{Mg}$ in plant shoots cultivated in the wastewater irrigated field was noted higher than cabbage grown in rain fed field (Figures $5 \mathrm{~b}$ and $5 \mathrm{c}$ ). The concentration of $\mathrm{Mg}$ in the plant in Site $\mathrm{A}$ was found maximum with $0.74 \mathrm{mg} \mathrm{kg}^{-1}$ and noted same in Site B and Site C of the wastewater irrigated field (Figure $5 b)$. On the other hand the amount of $\mathrm{Mg}$ in the cabbage shoots in rain fed field was almost same in Site A, Site $\mathrm{B}$ and Site $\mathrm{C}$.
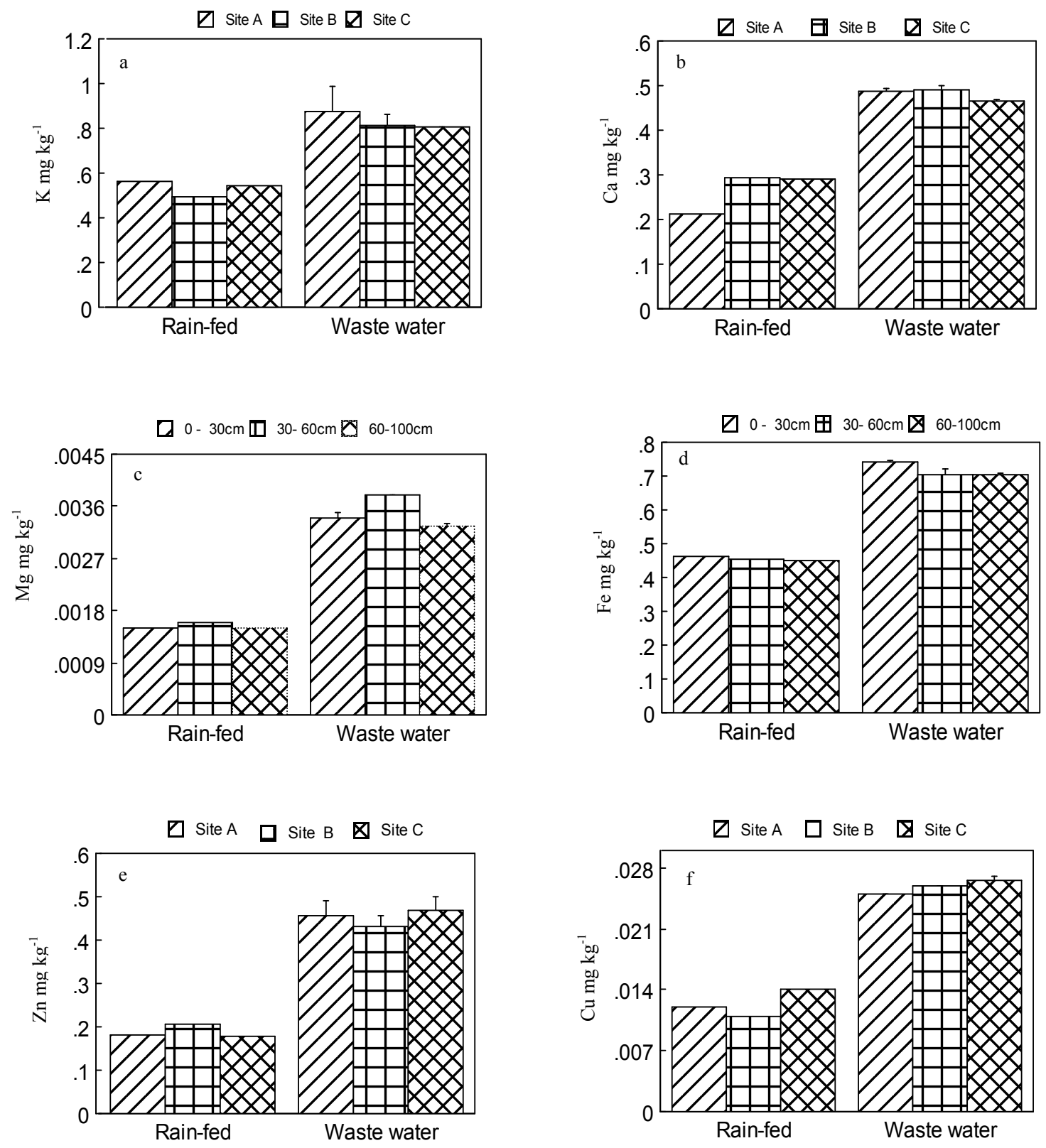

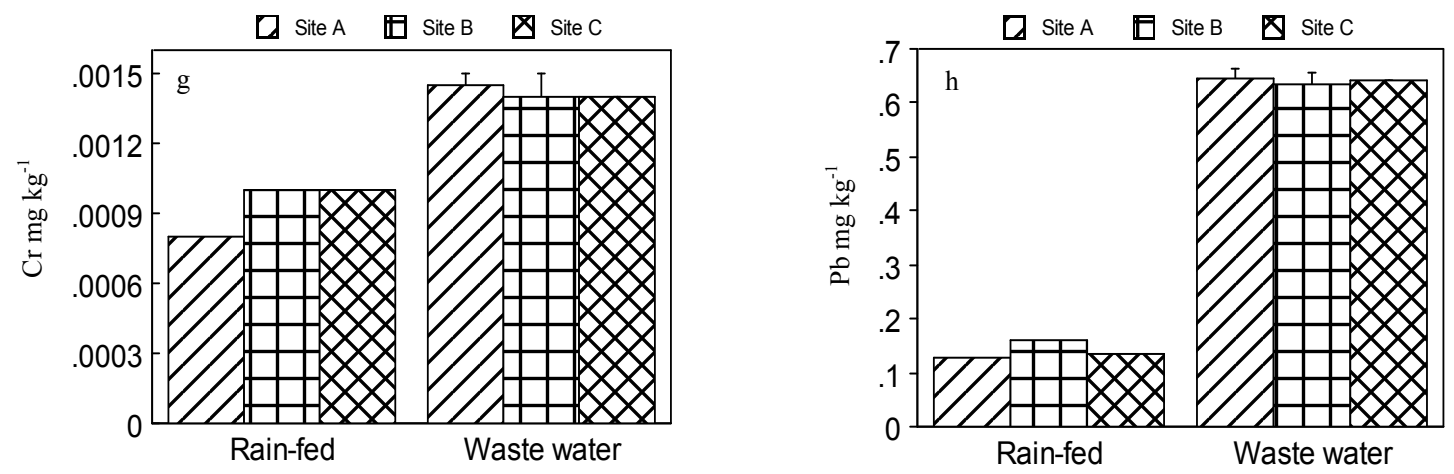

Figure 5. Concentration ( $\mathrm{mg} \mathrm{kg}^{-1}$ ) of $\mathrm{K}(\mathrm{a}), \mathrm{Ca}(\mathrm{b}), \mathrm{Mg}(\mathrm{c}), \mathrm{Fe}(\mathrm{d}), \mathrm{Zn}(\mathrm{e}), \mathrm{Cu}(\mathrm{f}), \mathrm{Cr}$ (g) and $\mathrm{Pb}(\mathrm{h})$ in Brassica Olerace $\mathrm{L}$ in wastewater irrigated and rainfed field

The Fe contents were found higher in the cabbage plant samples in all three sites of wastewater irrigated field and considerably decreased in the sample collected from Site A, B and C of the rain fed field (Figure 5d). Amount of $\mathrm{Zn}$ in the cabbage shoots of wastewater irrigated field were found significantly higher in all three sites A, B and C and observed lower in the Site A, B and C of the rain fed field (Figure 5e). In wastewater irrigated field the $\mathrm{Zn}$ contents varied in the order Site A $>$ Site B $>$ Site C (Table 10). Zn contents were found maximum $\left(0.21 \mathrm{mg} \mathrm{kg}^{-1}\right)$ in the plant sample of Site B. No significant differences were observed in the plant samples collected from Site A and Site $\mathrm{C}$ of the rain fed field. $\mathrm{Cu}$ concentration was also noted much higher in the plant samples of the wastewater irrigated field as compared to the rain fed filed (Figure $5 \mathrm{f}$ ). In the wastewater irrigated field $\mathrm{Cu}$ concentration found highest in the cabbage shoots collected from site $\mathrm{A}$. $\mathrm{Zn}$ and $\mathrm{Cu}$ values were less than $60 \mathrm{mg} \mathrm{kg}^{-1}$ and $40 \mathrm{mg} \mathrm{kg}^{-1}$ in Brassica oleracea $\mathrm{L}$. The concentration of $\mathrm{Cu}$ in the plant in all three sites were observed with marginal differences with variation in order Site $\mathrm{C}>$ Site B $>$ Site A.

$\mathrm{Cr}$ concentration was observed higher in the plant shoots collected from the sites of wastewater irrigated field and lower concentration was observed in the samples collected from the rain fed field (Figure $5 \mathrm{~g}$ ). $\mathrm{Cr}$ was observed in the rain fed field with lesser concentration in Site A as compared with Site B and Site C. In the wastewater irrigated field concentration of $\mathrm{Cr}$ was same in Site B and Site $\mathrm{C}$ with maximum value $(0.0014 \mathrm{mg}$ $\mathrm{kg}^{-1}$ ) in Site A. Higher amount of $\mathrm{Pb}$ content was found in the shoots of sample collected from the wastewater irrigated field as compared to the samples collected from adjacent rain fed field. There was no significant difference in the $\mathrm{Pb}$ content in the wastewater irrigated field in all three sites. In rain fed field the site wise concentration of $\mathrm{Pb}$ was Site $\mathrm{B}>$ Site $\mathrm{C}>$ Site A as shown in Figure $5 \mathrm{~h}$. Generally concentration of heavy metals $\mathrm{Fe}, \mathrm{Zn}, \mathrm{Cu}$ and $\mathrm{Pb}$ (except $\mathrm{Cr}$ ) in cabbage (Brassica oleracea $\mathrm{L}$.) was found significantly lesser in rain-fed field as compared with the adjacent wastewater irrigated field. Although total heavy metals in the soil are not available for plants and precise calculations cannot be done, still regression graph plotted between the total soil potassium and plant available potassium. Figure 6 shows increased concentration of plant available nutrient with increase in total soil contents. Simple regression analysis shows that with increase in the water soluble heavy metals the value of total heavy metals also increases. Same holds for $\mathrm{Fe}, \mathrm{Zn}, \mathrm{Cr}, \mathrm{Cu}$ and $\mathrm{Pb}$.
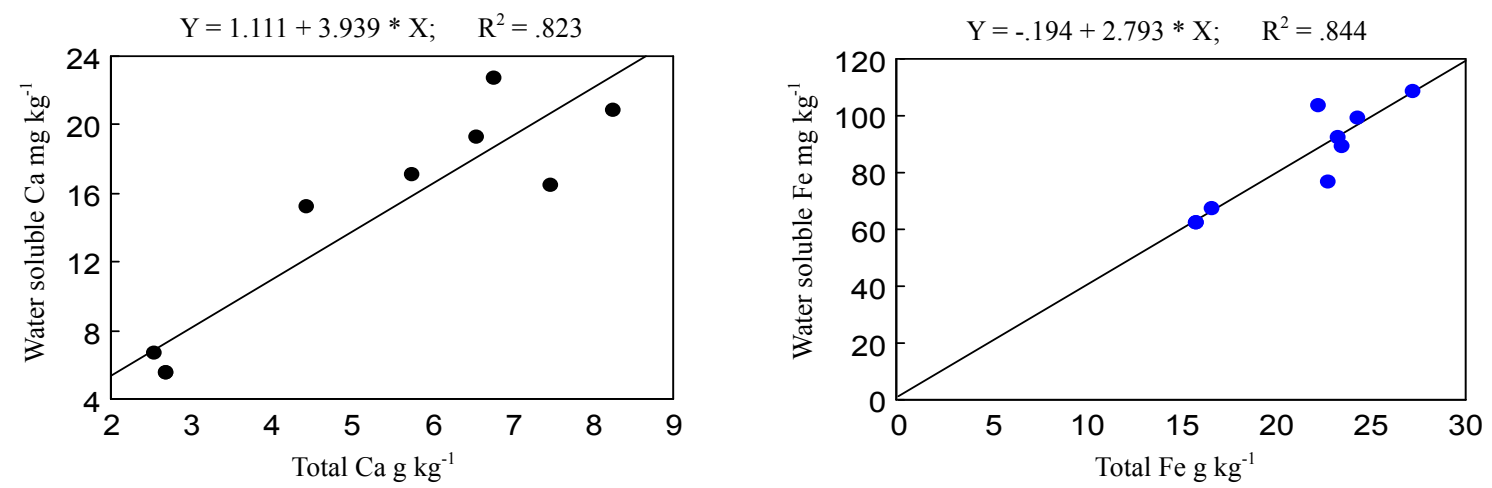

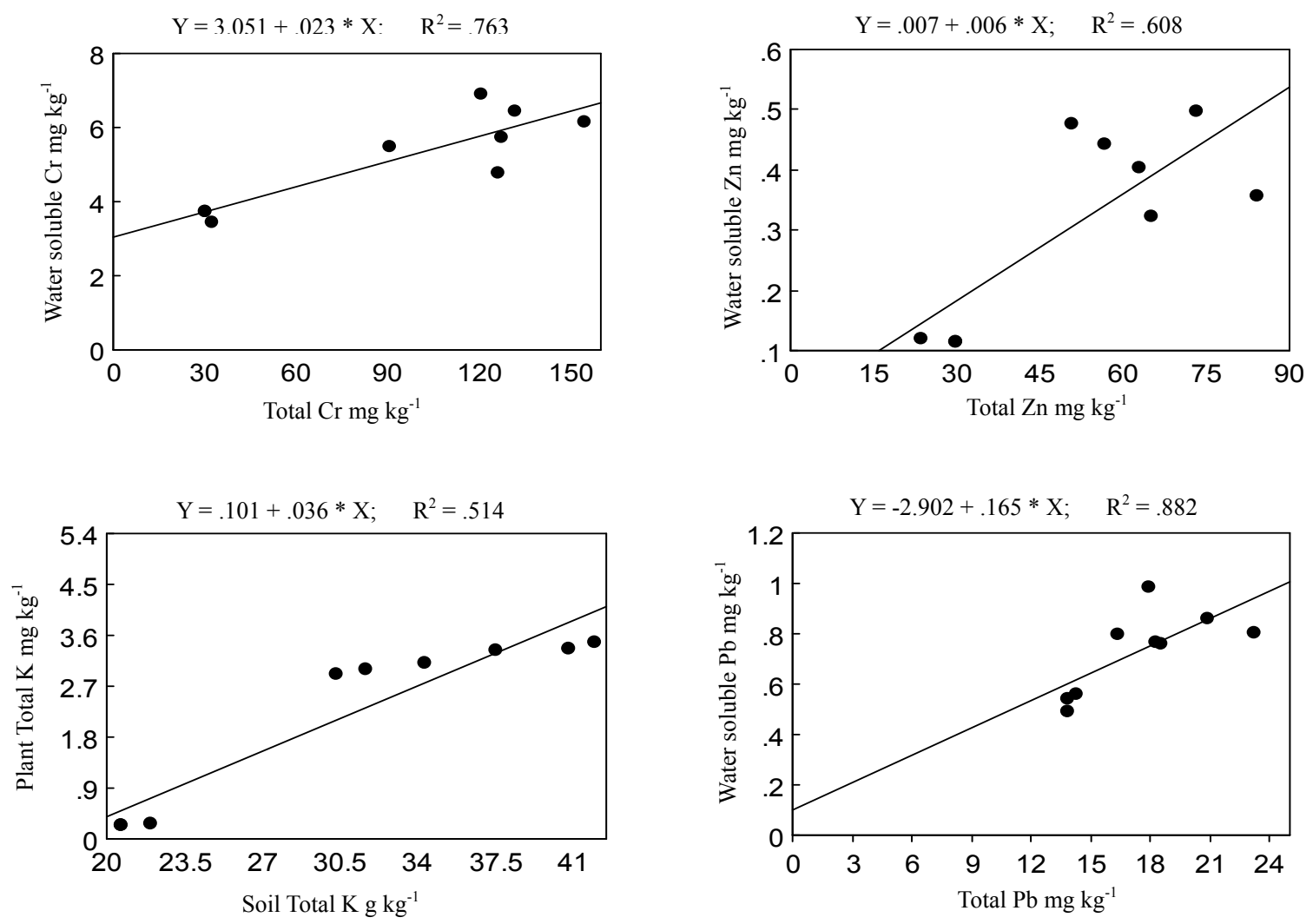

Figure 6. Simple regression analysis between the concentrations water soluble heavy metals the value of total heavy metals

\section{Discussion}

Main sources of water contamination are domestic waste products, paints, wrapping and packing materials, plumbing materials, vehicular emission, drainage from Abbottabad Maneshra road, limited scaled industry/hospital waste and auto workshops present in the vicinity of wastewater flow. For rain fed field concentration of water soluble $\mathrm{K}$ was minimum $19.97 \mathrm{mg} \mathrm{kg}^{-1}$ in top soil $(0-30 \mathrm{~cm})$ and noted maximum 23.14 $\mathrm{mg} \mathrm{kg}^{-1}$ in sub soil having depth $(60-100 \mathrm{~cm})$. The logical reason may be continuous leaching of $\mathrm{K}$ due to rain in vertical column. The accumulation of heavy metals in agricultural soils has been remained an increasing concern for scientists from all over the world (Facchinelli et al., 2001; Abollino et al., 2002).

In case of heavy metals in soil results showed that concentrations of heavy metals in rain-fed fields were found within the permissible limits. However in the wastewater irrigated soil the concentrations of all heavy metals understudy were significantly higher. Human activities such as industrial and energy production, vehicle exhaust, waste disposal, coal and fuel combustion were the potential sources for heavy metals to enter agricultural soils (Chen et al., 2005; Lucho-Constantino et al., 2005). In wastewater irrigated field water soluble Fe varied in order of 30-60 cm $>60-100 \mathrm{~cm}>0-30 \mathrm{~cm}$ whereas in rain fed field the concentration was $60-100 \mathrm{~cm}>0-30 \mathrm{~cm}>$ $30-60 \mathrm{~cm}$ (Figure 4a). In the rain fed field it is in permissible limits (in the range of 6-8 $\mathrm{mg} \mathrm{kg}^{-1}$ ). The analysis of bioavailable metals is probably more significant than the analysis of total content, because the former allows prediction of the risk of metal uptake by plants and its mobility in the system (Bell et al., 1991). The toxicity of heavy metals in soil significantly varied with soil characteristics and the time elapsed after contamination (Doelman \& Haanstra, 1984). Heavy metal concentrations in surface soil were significantly higher than those in the subsoil of cultivated field (Li et al., 1987). However, only soluble, exchangeable and chelated metal species in the soils were the labile fractions available for plants (Kabata-Pendias, 1993). At higher concentrations, some metals have strong toxic effects and are regarded as environmental pollutants (Nedelkoska \& Doran, 2000; Chehregani et al., 2005).

Heavy metals after accumulating in soil get transferred to vegetables grown on these soils (Malla et al., 2007). Natural levels of lead in surface soils are usually below 50 ppm (Chaney et al., 1984; Reagan \& Silbergeld, 
1989).

Over the period of time population growth has resulted in increased domestic and industrial effluents. Wastewater of the cities and towns is thus a readily available and costless source of irrigation. People prefer wastewater as they get huge quantities of vegetable yields because of the presence of nutrients like $\mathrm{Ca}, \mathrm{Mg}, \mathrm{K}$ in abundance without knowing its effect on soils, plants and ultimately on consumers. The superiority of wastewater over rain is addition of nutrients present in it. Results in Figures 1-8 indicated that water soluble heavy metals varied in soil in the order of $\mathrm{Fe}>\mathrm{Cr}>\mathrm{Pb}>\mathrm{Zn}>\mathrm{Cu}$ irrespective of the soil depth and irrigation source. For extractable heavy metals the order was observed as $\mathrm{Fe}>\mathrm{Cr}>\mathrm{Pb}>\mathrm{Zn}>\mathrm{Cu}$ for rain fed field across all soil layers. In wastewater irrigated field similar concentrations were observed except the order of $\mathrm{Zn}$ and $\mathrm{Cu}$ was changed. For total heavy metals in all layers of soil the order was noted as $\mathrm{Fe}>\mathrm{Cu}>\mathrm{Cr}>\mathrm{Pb}>\mathrm{Zn}$ irrespective of the source of irrigation. On the other hand concentrations of water soluble essential elements under study varied as $\mathrm{Mg}>\mathrm{Ca}>\mathrm{K}$ for both rain fed and wastewater irrigated field. Heavy metal uptake by crops growing in contaminated soil is a potential hazard to human health because of transmission in the food chain (Gincchio et al., 2002; Friesl et al., 2006). There is also a concern with regard to heavy metal transmission through natural ecosystems (MacFarlane \& Burchett, 2002; Walker et al., 2003). Parameters related to the heavy metal uptake have been used as sensitive indicators of heavy metal toxicity (Nannipieri et al., 1997; Wilke, 1991) Heavy metal behaviour in soils and plant uptake are strongly dependent on the nature of the metal, sludge/soil physico-chemical properties and plant species (McBride, 2003). While growing edible vegetables in contaminated soils, it is important to know the extent of accumulation in plants and their different parts. The toxicity of heavy metals in soil significantly varies with soil characteristics and the time elapsed after contamination (Doelman \& Haanstra, 1984). Heavy metals are easily accumulated in the edible parts of the leafy vegetables. Vegetables take up heavy metals and accumulate them in their edible and in inedible parts in quantities high enough to cause clinical problems both to animals and human beings consuming these metal rich plants. Application of wastewater resulted in marked increase in cabbage (Brassica Oleracea L.) growth as compare to the rain fed field. Plant that received wastewater produced greater biomass then those received rain water. This superiority of wastewater over rain fed could possibly be due to the addition of nutrients present in the wastewater. Although sludge compost increase biomass of the crop but at the same time toxic metals can be transferred and concentrated into plant tissues from the soil (Alloway, 1995). Metals in water soluble fraction may be readily leachable and bioavailable in the environment. Contaminants in bulk soil might be transferred into soil solution, making them available to roots.

\section{Conclusions}

The study concluded that increased heavy metals were observed in the wastewater irrigated field as compared with the adjacent rain fed field. Total heavy metals were higher in wastewater irrigated field than rain fed field. For total heavy metals in all layers of soil vertical column the order was noted as $\mathrm{Cr}>\mathrm{Zn}>\mathrm{Pb}>\mathrm{Cu}>\mathrm{Fe}$ for wastewater irrigated field and $\mathrm{Cr}>\mathrm{Zn}>\mathrm{Pb}>\mathrm{Fe}>\mathrm{Cu}$ for rain fed field for all soil depths. The rain fed soil exhibited lower concentrations of water soluble heavy metals as compared to wastewater irrigated field which may reduce the risk of metal transfer from soil to plants. $\mathrm{Fe}, \mathrm{Cu}$ and $\mathrm{Cr}$ were found higher in wastewater irrigated field whereas $\mathrm{Pb}$ and $\mathrm{Zn}$ showed their minimum concentrations. $\mathrm{Mg}$ and $\mathrm{Ca}$ were higher in both rain fed and wastewater irrigated soils whereas significantly decreased $\mathrm{K}$ was observed in both. We conclude that wastewater irrigation causes heavy metal accumulation in both soils and the plants. The use of wastewater for agriculture carefully rationalized before wastewater irrigation.

\section{References}

Abollino, O., Aceto, M., Malandrino, M., Mentasi, E., Sarzanini, C., \& Petrella, F. (2002). Heavy metals in agricultural soils from Piedmont, Italy. Distribution, speciation and chemometric data treatment. Chemosphere, 49, 545-557. http://dx.doi.org/10.1016/S0045-6535(02)00352-1

Alloway, B. J. (1995). Heavy Metals in Soils. Chapman \& Hall, London. http://dx.doi.org/10.1007/978-94-011-1344-1

American Public Health Association, Inc. (APHA). (2005). Standard Methods for the Examination of Water and Wastewater (21st ed.). New York, NY.

Bell, J. M., \& Keith, M. O. (1991). A survey of variation in the chemical composition of commercial canola meal produced in Western Canadian crushing plant. Can. J. Anim. Sci., 71(2), 469-480. http://dx.doi.org/10.4141/cjas91-056

Burn, L. A., Maillet, J., Hinsinger, P., \& Pepin, M. (2001). Evaluation of copper availability to plants in 
copper-contaminated vineyard soils. Environ. Pollut., 111, 293-302. http://dx.doi.org/10.1016/S0269-7491(00)00067-1

Chaney, R. L. (1984). The potential for heavy metal exposure from urban gardens and soils (pp. 37-84).

Chehregani, A., Malayeri, B., \& Golmohammadi, R. (2005). Effect of heavy metals on the developmental stages of ovules and embryonic sac in Euphorbia cheirandenia. Pak. J. Biol. Sci., 8, 622-625. http://dx.doi.org/10.3923/pjbs.2005.622.625

Chen, T. B., Zheng, Y. M., Lei, M., Huang, Z. C., Wu, H. T., Chen, H., ... Tian, Q. Z. (2005) Assessment of heavy metal pollution in surface soils of urban parks in Beijing, China. Chemosphere, 60, 542-551. http://dx.doi.org/10.1016/j.chemosphere.2004.12.072

Doelman, P., \& Haanstra, L. (1984). Short-term and long-term effects of cadmium, chromium, copper, nickel, lead and zinc on soil microbial respiration in relation to abiotic soil factors. Plant Soil, 79(3), 317-327. http://dx.doi.org/10.1007/BF02184325

Facchinelli, A., Sacchi, E., \& Mallen, L. (2001). Multivariate statistical and GIS-based approach to identify heavy metal sources in soils. Environment Pollution, 114, 313-324. http://dx.doi.org/10.1016/S0269-7491(00)00243-8

Friesl, W., Friedl, J., Platzer, K., Horak, O., \& Gerzabek, M. H. (2006). Remediation of contaminated agricultural soils near a former $\mathrm{Pb} / \mathrm{Zn}$ smelter in Austria: batch, pot and field experiments. Environ. Pollut., 144, 40-50. http://dx.doi.org/10.1016/j.envpol.2006.01.012

Gee, G. W., \& Bauder, J. W. (1986). Particle-size analysis. In A. Klute (Ed.), Methods of soil analysis (2nd ed., Part 1, Agron. Monogr. 9, pp. 383-411). ASA and SSSA, Madison, WI.

Gincchio, R., Rodriguez, P. H., Badilla-Ohlbaum, R., Allen, H. E., \& Lagos, G. E. (2002). Effect of soil copper content and $\mathrm{pH}$ on copper uptake of selected vegetables grown under controlled conditions. Environ. Toxicol. Chem., 21, 1736-1744. http://dx.doi.org/10.1002/etc.5620210828

Haq, A. U., Bates, T. E., \& Soon, Y. K. (1980). Comparison of extractants for plant-available zinc, cadmium, nickel, and copper in contaminated soils. Soil Sci. Sot. Am. J., 44, 772-777. http://dx.doi.org/10.2136/sssaj1980.03615995004400040023x

IBSRAM. (1994). Methodological guidelines for IBSRAM's soil management networks (2nd ed.). International Board for Soil Research and Management, Bangkok

Kabata-Pendias, A. (1993). Behavioural properties of trace metals in soils. Applied Geochemistry, 2, 3-9. http://dx.doi.org/10.1016/S0883-2927(09)80002-4

Li, Y. J., Ning, R. A., \& Wang, D. Z. (1987). Mapping of soil background content map in 11 elements in aquic soils of the Yellow River downstream. Agro-Environ., 6,18-21.

Lindsay, W. L., \& Norvell, W. A. (1978). Development of a DTPA soil test for zinc, iron, manganese and copper. Soil Sci. Sot. Am. J., 42, 421-428. http://dx.doi.org/10.2136/sssaj1978.03615995004200030009x

Lucho-Constantino, C. A., Álvarez-Suárez, M., Beltrán-Hernández, R. I., Prieto-Garcia, F., \& Poggi-Varaldo, H. M. (2005). A multivariate analysis of the accumulation and fractionation of major and trace elements in agricultural soils in Hidalgo State, Mexico irrigated with raw wastewater. Environment International, 31, 313-323. http://dx.doi.org/10.1016/j.envint.2004.08.002

MacFarlane, G. R., \& Burchett, M. D. (2002). Toxicity, growth and accumulation relationships of copper, lead and zinc in the grey mangrove Avicennia marina (Forsk.). Vierh. Mar. Environ. Res., 54, 65-84. http://dx.doi.org/10.1016/S0141-1136(02)00095-8

Malla, R., Tanaka, Y., Mori, K., \& Totawat, K. L. (2007). Short term effect of sewage irrigation on chemical buildup in soil and vegetables. The Agric. Engg. Int. The CIGR J., IX, LW 07 006, 14.

Martens, D. C. (1968). Plant availability of extractable boron, copper, and zinc as related to selected soil properties. Soil Sci., 106, 23-28. http://dx.doi.org/10.1097/00010694-196807000-00004

McBride, M. B. (2003). Toxic metals in sewage sludge-amended soils: Has promotion of beneficial use discounted the risks? Adv. Environ. Res., 8, 5-19. http://dx.doi.org/10.1016/S1093-0191(02)00141-7

Mehlich, A. (1984) Mehlich 3 soil test extractant: A moditication of Mehlich 2 extractant. Commun. Soil Sci. Plant Anal., 15, 1409-1416. http://dx.doi.org/10.1080/00103628409367568

Nannipieri, P., Badalucco, L., Landi, L., \& Pietramellara, G. (1997). Measurement in assessing the risk of 
chemicals to the soil ecosystem. In J. T. Zelikoff (Ed.), Ecotoxicology: Responses and Risk Assessment, an OECD Workshop. SOS Publications, Fair Haven, NJ.

Nedelkoska, T. V., \& Doran, P. M. (2000). Characteristics of heavy metal uptake by plant species with potential for phytoremediation and phytomining. Minerals Engineering, 13, 549-561. http://dx.doi.org/10.1016/S0892-6875(00)00035-2

Nriagu, J. O. (1991). Human influence on the global cycling of trace metals. In J. G. Farmer (Ed.), Heavy Metals in the Environment (Vol. 1, pp. 1-5). CEP Consultants Ltd., Edinburgh, UK.

Oliver, M. A. (1997). Soil and human health: A review. European Journal of Soil Science, 48(4), $573-592$. http://dx.doi.org/10.1046/j.1365-2389.1997.00124.x

Reagan, P. L., \& Silbergeld, E. K. (1989). Establishing a health based standard for lead in residential soils. Environ Geochem Health, 12(Suppl.), 198-230.

SAS. (1999). Stat View reference (3rd ed.). SAS Institute Inc., Cary, NC, USA.

Speir, T. W., Kettles, H. A., Parshotam, A., Searle, P. L., \& Vlaar, L. N. C. (1995). A simple kinetic approach to derive the ecological dose value, ED50, for the assessment of $\mathrm{Cr}(\mathrm{VI})$ toxicity to soil biological properties. Soil Biol. Biochem., 27(6), 801-810. http://dx.doi.org/10.1016/0038-0717(94)00231-O

Thomas, G. W. (1982). Exchangeable cations. In A. L. Page, R. H. Miller \& D. R. Keeney (Eds.), Methods of Soil Analysis (Part 2, Agronomy series No. 9, pp. 159-165). Am. Soc. Agronomy and Soil Sci. Soc. Am. Inc., Publ. Madison W. I. USA.

Walker, D. J., Clemente, R., Roig, A., \& Bernal, M. P. (2003). The effects of soil amendments on heavy metal bioavailability in two contaminated Mediterranean soils. Environ. Pollut., 122, $303-312$. http://dx.doi.org/10.1016/S0269-7491(02)00287-7

Wilke, B. M. (1991). Effects of single and successive additions of cadmium, nickel and zinc on carbon dioxide evolution and dehydrogenase activity in a sandy luvisol. Biol. Fert. Soil., 11(1), 34-37. http://dx.doi.org/10.1007/BF00335831

Zulfiqar, A. B., Qaisar, M., Iftikhar, A. R., Amir, H. M., Naim, R., \& Donglei, W. (2011). Integrated chemical treatment of municipal wastewater using waste hydrogen peroxide and ultraviolet light. Physics and Chemistry of the Earth, 36, 459-464. http://dx.doi.org/10.1016/j.pce.2010.03.024

\section{Copyrights}

Copyright for this article is retained by the author(s), with first publication rights granted to the journal.

This is an open-access article distributed under the terms and conditions of the Creative Commons Attribution license (http://creativecommons.org/licenses/by/3.0/). 